\title{
Assessing the impact of watershed land use on Kebena river water quality in Addis Ababa, Ethiopia
}

\author{
Kalkidan Asnake ${ }^{1 *}$, Hailu Worku$^{1}$ and Mekuria Argaw ${ }^{2}$
}

\begin{abstract}
Background: The impact of watershed land-use on surface water quality is one of the under researched areas in mega cities of the developing countries like Addis Ababa. The study examined the impact of watershed land uses on the Kebena river water quality within its seasonal and spatial variation and assessed the relationship between river water pollution and dominant land-use types in the sub-watersheds.

Method: The main land use types in the sub-watersheds were digitized from aerial photograph of 2016, and quantified for water quality impact analysis. Water samples were collected from the main Kebena river and the three sub-watersheds source and outlet points. A total of 128 samples were collected during the dry and wet seasons of 2016 and 2017 and analyzed for various water quality parameters. The study employed ANOVA, independent t-tests and multiple regression analysis to examine variations in water quality and assess the influence of the different land uses on water quality.
\end{abstract}

Results: Forest, built-up area and cultivated lands are the three major land use types in the Kebena watershed accounting for $39.14,32.51$ and $27.25 \%$ of the total area, respectively. Kebena catchment is drained by three subwatersheds namely, Denkaka (44.9\% cultivated land), Little-Kebena (60.87\% forested) and Ginfle ( $90.44 \%$ urban land). The concentration of pollutants in the Kebena river was significantly higher $(P<0.001)$ in the dry season than in the wet season. However, when compared to surface water quality standards, both the dry and wet season water quality records are exceptionally high. The urban and forest dominated sub-watersheds contribute significantly high amount of $(P<0.001)$ pollutant loads to the river which is associated with high runoff from impervious surfaces and sewerage discharge to the river from nearby urban settlements.

Conclusion: Integrating watershed planning with land use planning is of paramount importance to address water quality problems in urban areas. Thus, in the urban dominated sub-catchment, land-use planning should aim to relocating river front communities, providing sufficient river buffer-zones and forwarding appropriate storm water management schemes. In the forested sub-catchment, planning should protect, retain and enhance the existing natural green spaces through open space planning, and management schemes while providing wide river-buffer with natural vegetation cover to minimize pollution load to urban rivers from agriculture dominated sub-watershed.

Keywords: Addis ababa, Kebena river, Land use land cover, Sub-watershed, Water quality

\footnotetext{
${ }^{*}$ Correspondence: kalkidan.asnake@eiabc.edu.et

1 Ethiopian Institute of Architecture, Building Construction and City

Development, Addis Ababa University, P.O. Box 518, Addis Ababa, Ethiopia

Full list of author information is available at the end of the article
}

\begin{abstract}
Background
Fresh water ecosystems such as lakes, wetlands and waterways, shape and support different modes of life that, along with the water itself, provide goods and services of vital value to human societies (Arthington et al. 2010; Baron et al. 2002). A secure supply of clean and
\end{abstract}


fresh water is needed for all human beings. In the developed countries, fresh water ecosystems supply water that is directly treated and distributed to consumers (Arthington et al. 2010). Whereas, in the developing countries, hundreds and millions of people continue to use water directly from natural sources for drinking and domestic purposes (Worku and Giweta 2018; Seyoum et al. 2017).

The negative impact of watershed land use on water quality has been in discussion for a long time (Ding et al. 2015; Barbec 2009; Lee et al. 2009; White and Greer 2006; Findlay and Taylor 2006; Goonetilleke et al. 2005; Brabec et al. 2002; Paul and Meyer, 2001; Klein, 1979). The impacts are observed mainly on water quality as caused by point and non-point pollution sources (Wilson, and Weng 2010; Paul and Meyer 2001).

Point source pollution is the result of a direct release of pollutants from nearby known sources (Sliva and Williams 2001). This, increases the impact of watershed land use on river water quality particularly with certain types of land uses such as settlements, institutions, agriculture fields, industries, water treatment plants, and mining fields that directly release their waste to rivers (Gyawali et al. 2013; Spanhoff et al. 2012; Hudak and Banks 2006). On the other hand, non-point source pollution is caused by poor stormwater management in a watershed, where most of the impacts are directly related to the increasing proportion of watershed imperviousness (Sliva and Williams 2001). Urban land-use features such as roof covers and road construction, primarily modify watershed land cover from pervious surface to impervious, changing the runoff water by increasing the volume of stormwater flow to rivers (Xu et al. 2019; Findlay and Taylor 2006; Doerfer and Urbona 2004; Arnold and Gibbons 1996; Leopold 1968). This land use change results in high amount of urban runoff containing high levels of pollutants affecting the water quality of the receiving water bodies (Lim and Lu 2016; Ding et al. 2015). In line with this, the impact of urbanized watershed on stream water quality impairment is first observed when imperviousness reaches $10-12 \%$ and increases with the change in land use, starting to become severe when the imperviousness reaches 30\% ( $\mathrm{Li}$ et al. 2008; Arnold and Gibbons 1996; Klein 1979). Arnold and Gibbons (1996) further discussed that the amount of runoff doubles when catchment impervious surface cover reaches between 10-20 percent, triples between $35-50$ percent, and intensifies to more than five times when imperviousness increases to 75-100 percent than in a forest covered watershed land use.

The high rate of watershed urbanization in developing cities exerts extreme pressure on urban rivers as urban centers are often expanding without proper planning and adequate waste disposal and infrastructure facilities provision (Liang et al. 2018; Yabe et al. 2010). Thus, urban rivers in developing cities are threatened by high rate of water pollution and rapid loss of biodiversity.

Under normal circumstances, urban plans guide urbanization through the provision of land use plans, road network plans, different infrastructure provision plans and implementation strategies and procedures (Patricia et al. 2013; Carter 2007). Consequently, the nature and location of development, which mostly is decided by urban planners significantly influences both the generation and resolution of environmental problems (Patricia et al. 2013; Barbec 2009; Carter 2007). Though urban plans play a vital role to balance the various development needs and the provisional capacity of available land, it is not common to integrate anticipated environmental pressures and further study the impacts of upcoming developments on natural resources (Carter 2007). This is especially true with river water quality related issues that are addressed by a different entity apart from major urban planning factors, which have greatly affected rivers as most projects originate from urban planning decisions (Cettner et al. 2013; Patricia et al. 2013; Carter 2007).

To maintain the balance between nature conservation and development demand in an urban setting, watershed planning and management is becoming a key approach to minimize the impact of watershed land use on surface waters. Historically, watershed planning and management were used to solve flood-related problems (Ward et al. 2012). Currently, however, attempts are being made to study the relationship between land use, the flow and storage of water, and water quality (Doerfer and Urbonas 2004). Moreover, habitat conditions, ecology, and community values are taken into consideration as the vital aspect of watershed-based planning and management approach (US Environmental Protection Agency 1995). Watershed planning and management also enhance program efficiency, improve coordination among institutions, and balance the allocation of resources and funding (Browner 1996; Doerfer and Urbonas 2004).

In Addis Ababa, rivers and riversides are among the natural resources that are negatively affected by the rapid watershed urbanization (Worku and Giweta 2018; AACPPO 2017; Yohannes, and Elias 2017; Mazhindu et al. 2012; Gebre and Rooijen 2009; Alemayehu 2001). Land-use change and deforestation in and around Addis Ababa have resulted in high level of river water pollution, which has become a threat to human health and native biodiversity causing habitat loss and fragmentation (AACPPO 2017; Weldegebriele et al. 2012; Beyene et al. 2009). Kebena River is one of the main tributaries of the Awash River basin, originating from the northern tip of the Entoto Mountain in Addis Ababa. Despite the fact that many people use Kebena river water for various domestic purposes, the river is continually exposed 
to contamination by solid and liquid wastes from the different land uses within its watershed (Worku and Giweta 2018; Seyoum et al. 2017).

Thus, the aim of this study is to examine the impact of watershed land use on the Kebena river water quality across spatial and seasonal continuum. Furthermore, the study explores the linkage between the river water pollution and the dominant land-use types within the different sub-catchments of the Kebena river watershed.

\section{Methods and materials}

\section{Description of the study area}

Generally, the Addis Ababa river catchments are drained by two major river systems such as Tinishu Akaki (Little Akaki) and Tiliku Akaki (Great Akaki) rivers. The two rivers originate from the Entoto Mountain chains and flow down to the man-made Lake, the Aba Samuel water reservoir, at the lower end of the City (Gebre and Rooijen 2009; Beyene et al. 2009). This study was conducted in the Kebena river watershed draining the upper most central part of the city of Addis Ababa (Fig. 1). We selected Kebena River and its watershed for this study because of its prime location in central part of the city and due to the fact that the river water is used by local people for domestic purposes despite the high level of pollution affecting the quality of the river water (Worku and Giweta 2018).

The Kebena River watershed is characterized by mountainous landscape that extends from the top of Entoto Mountain to the central part of the City in the lower end. The watershed is situated in the geographical location between of $8^{\circ} 9^{\prime} 50^{\prime \prime} \mathrm{N}-9^{\circ} 6^{\prime} 60^{\prime \prime} \mathrm{N}$ latitude, and $38^{\circ} 45^{\prime}$ $30^{\prime \prime}-38^{\circ} 49^{\prime} 30^{\prime \prime} \mathrm{E}$ longitude (Fig. 1). The total estimated area covers about 5,150 ha and the altitudinal range falls between 2000 m.a.s.l in the lower end to 3200 m.a.s.l at the top of the Entoto Mountain.

The volume of water flow in the river greatly varies during the dry and wet seasons. This seasonal flow variation obviously causes variations in the concentrations of pollutants in the river water. In Addis Ababa, the dry season extends from mid-September to end of May while the main rainy season extends from June to -September. During the short rainy season from February to April, the city gets fairly wet and river flows increase temporarily. During the dry season, the city experiences an average temperature of $6^{\circ} \mathrm{C}$ to $29^{\circ} \mathrm{C}$. Whereas, the long rainy

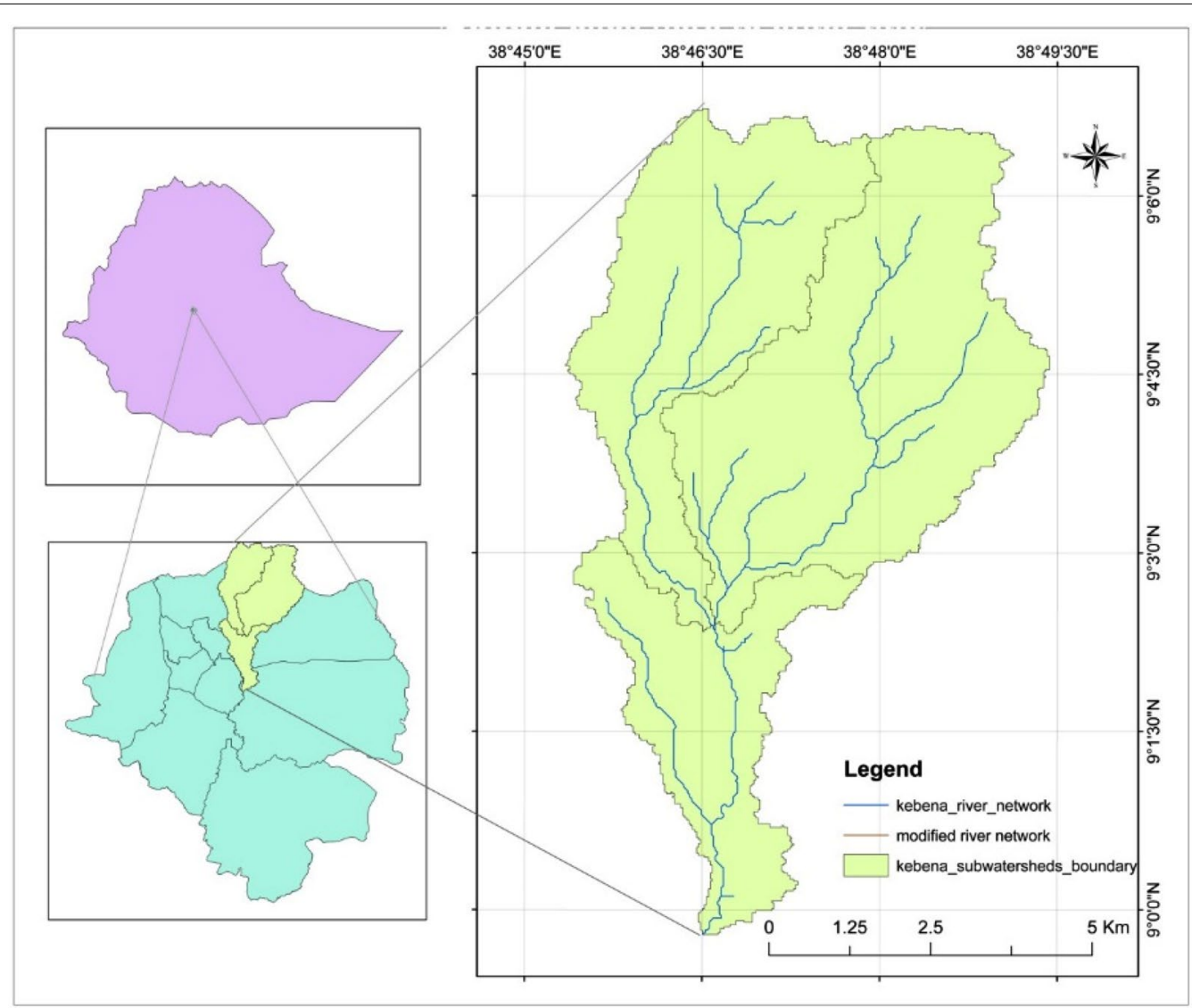

Fig. 1 Location Map of the Kebena watershed in Addis Ababa 
season is from June to September and the largest amount of rain falls during this period, which averages to about $900 \mathrm{~mm}$ as calculated from 30 years of meteorological data (Fig. 2).

\section{Watershed land use analysis}

Major land use types (Fitzpatrick et al. 2007) in the Kebena watershed were manually digitized from a high resolution aerial photograph of the year 2016, which was obtained from the Ethiopian Mapping Authority, using ArcGIS 10.1 software. With the assumption that different land use types will have differentiated impact on water quality, the land use types were categorized into four dominant land use groups: (1) forested land use, which include natural forest, Eucalyptus globulus plantation and riverine vegetation, (2) built-up area (impervious surfaces), which include residential, light industries, hospitals, schools and other impervious land uses (3) Cultivated land (pervious surfaces), which include grassland and agriculture land, and (4) bare land, which include degraded bare soil and rock surfaces (Fig. 3).

The $30 \mathrm{~m}$ Digital Elevation Model (DEM) of the watershed was used to determine flow-path directions of three distinct sub-watersheds by using the hydrology tool of spatial analyst extension in ArcGIS version 10.1. The flow-path-direction grid cells were used to delineate the catchments of the sub-watersheds. The three distinct sub-watersheds were the Ginfle sub-watershed with a catchment dominated by urban land use; Denkaka subwatershed dominated by agriculture land use and littleKebena sub-watershed dominated by forest land use. The geodatabase has been transformed into a common digital

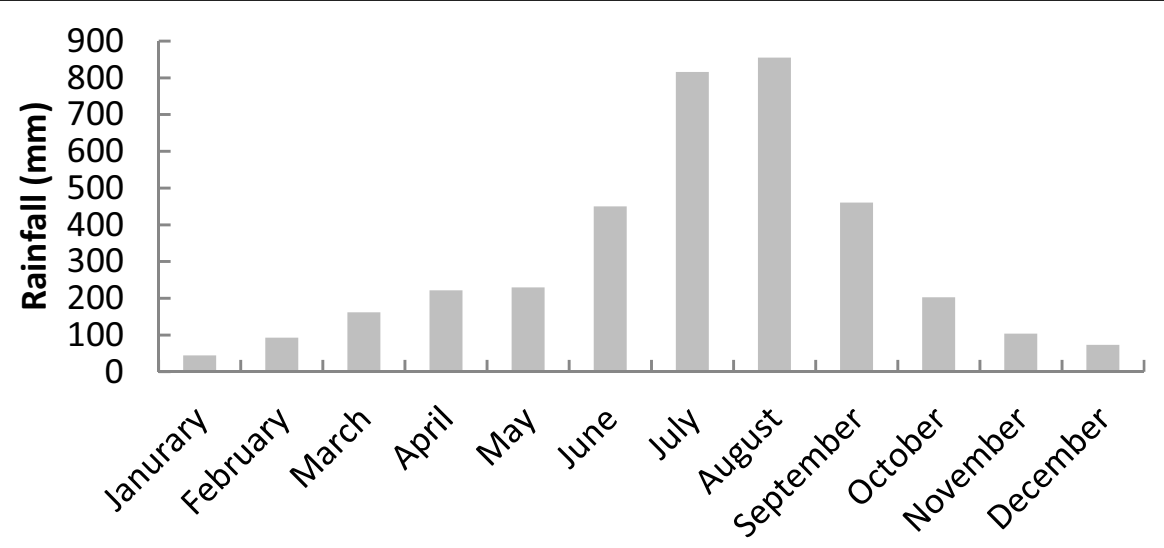

Months

a

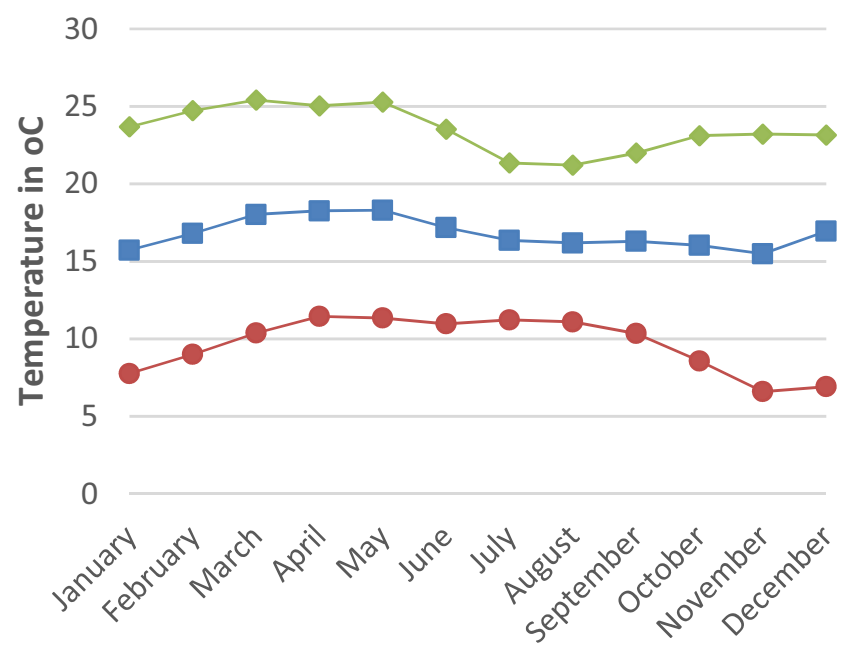

Months

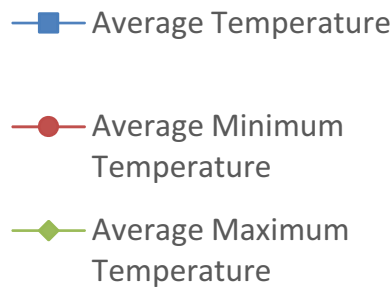

b

Fig. 2 Mean annual rainfall (a) and temperature distribution (b) in the city of Addis Ababa (averaged from 30 years data record) 


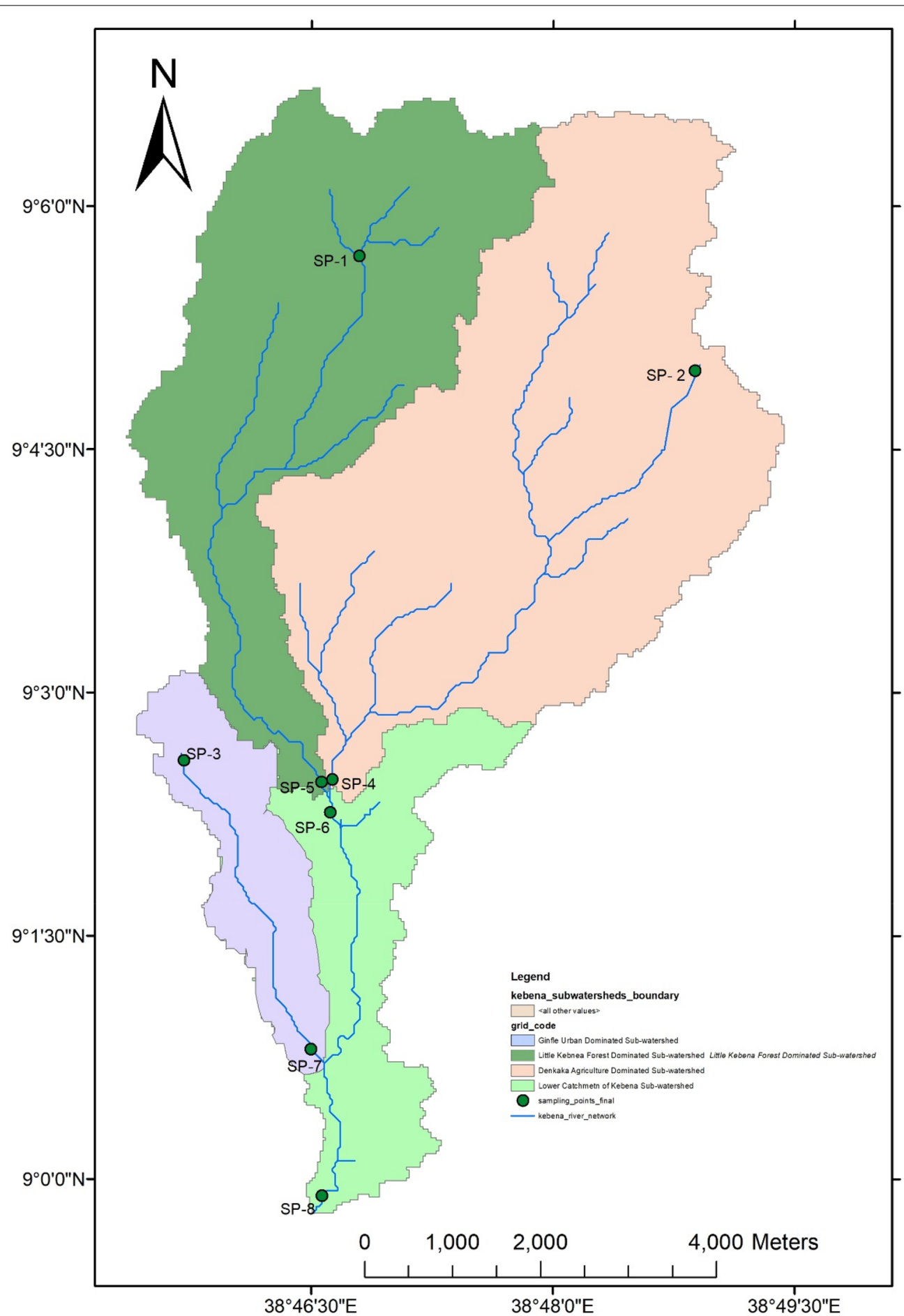

Fig. 3 Map of the Kebena Watershed and its sub-watersheds

format and projected onto the Universal Trans Mercator (UTM) system for vector data analysis in ArcGIS version 10.1 (Sliva, and Williams 2001). The three outlet points of the sub-watersheds were used as sampling sites for the water samples collection. The main outlet of the entire Kebena watershed was included as one of the sampling site to capture the impact of the lower catchments on the river water quality. 


\section{Water quality analysis}

Water quality analysis was conducted for two main reasons (1) to study the overall water quality situation of Kebena river during the dry and wet seasons and (2) to identify the effect of major land use types on the water quality of the Kebena river sub-watersheds. For the water quality analysis, water samples were collected at the sources and outlet points of the sub-watersheds and at the main outlet of the Kebena river watershed. A total of eight sampling sites (each for the dry and wet seasons) were selected to collect the water samples from the river (Chebet et al. 2020; Goshu 2007; Sliva and Williams 2001). The seasonal samples were collected for two consecutive years in 2016 and 2017. A total of 128 water samples were collected during the dry and wet seasons of the sampling years. The wet season samples were taken between June and August while the dry season samples were taken between January and March.

The water samples were collected using a two liter polyethylene plastic bottle at a depth of $20 \mathrm{~cm}$ below the water surface and at a distance of $1.5 \mathrm{~m}$ from the edge towards the middle of the river. The sampling bottles were rinsed very well before taking the samples. The water samples were taken by dipping the opening of the sampler in the upslope direction. The water samples were stored in iceboxes and transported within four hours to the Addis Ababa Environmental Protection Authority for laboratory analysis. The water samples were analyzed for $\mathrm{pH}, \mathrm{EC}$, TDS, TSS, BOD, COD, Total Nitrogen, Total Phosphorous, Ammonia, and Chloride. Analyses were done by following standard procedures as outlined in APHA (2005). The water quality analysis results were compared against existing national and international standards for surface water quality.

\section{Statistical analysis}

Statistical analyses were performed to examine the relationships between land-use variables and water quality parameters (Sliva and Williams 2001). A oneway ANOVA test was conducted to compare mean values of water quality parameters among the subwatersheds for different water quality indicators and seasons. Independent t-Test was conducted to compare the mean values of the different water quality indicators for the wet and dry seasons. Multiple regression analysis was applied to determine whether watershed land use factors have positive or negative influence on separate water quality indicators using three predictor land use variables (agricultural, forested, and urban land use variables).

\section{Results}

Watershed Land Use types and distribution

The Kebena river watershed covers a total area of $5,247.60$ ha. The forest land, which includes the natural forest, the Eucalyptus globulus plantation and riverine vegetation, is the dominant land use and accounted for $39.14 \%$ of the total land area. Built-up area/ settlement is the second largest land use accounting for $32.51 \%$ of the total land, which is followed by cultivated land covering $27.1 \%$ of the total area. The area with bare soil and rock surface is very small and accounted only $1.1 \%$.

Among the three major sub-watersheds, the agriculture dominated Denkaka sub-watershed is largely covered by field crops (44.9\%), forest land (34.14\%) and built-up area (19.1\%). The rest is bare soil and rock surface (Table 1). The forest dominated little-Kebena sub-watershed is predominantly covered by natural forest mixed with Eucalyptus plantations (60.87\%), built-up area (21.5\%) and cultivated land (17\%). The sub-watershed accommodated pocket areas of highly congested settlements, particularly in the lower parts and along the river banks. The urban dominated Ginfle sub-watershed is the smallest with more than $90 \%$ of the area covered by built-up area and dense settlements with only about $7.5 \%$ of the land with field crops, $1.5 \%$ of the land with riverine vegetation and forests (Fig. 4; Table 1).

\section{Seasonal variations in water quality of the Kebena watershed}

The result of the analysis showed that there are significantly high seasonal variations in the concentration of the water quality indicators. As shown in Table 2 below, the river water carries significantly higher loads of pollutants during the dry season than in the wet season $(P<0.001$, $P<0.05)$. Accordingly, mean values of all parameters except TSS, COD, and BOD showed significant variation at $P<0.001$.

The mean values of TSS, EC, Ammonia, and TN are significantly higher during both the wet and dry seasons compared to surface water quality standards set by WHO, which is $25 \mathrm{mg} / \mathrm{l}, 0.60-0.18 \mu \mathrm{s} / \mathrm{cm}, 1.5 \mathrm{mg} / \mathrm{l}, 10 \mathrm{mg} / \mathrm{l}$, respectively. On the contrary, Chloride and COD showed significantly lower values in the wet season compared to surface water quality standards set by UNEP, and WHO which is $200-300$ and $250 \mathrm{mg} / \mathrm{l}$, respectively (Table 2).

\section{Seasonal and spatial variations of water quality in the sub-watersheds}

The results from this study show that in the wet season, the mean $\mathrm{pH}$ level at the source of the river is 6.73. The lowest mean value of $\mathrm{pH}$ was recorded in the agriculture dominated Denkaka sub-watershed, which is 5.64, 


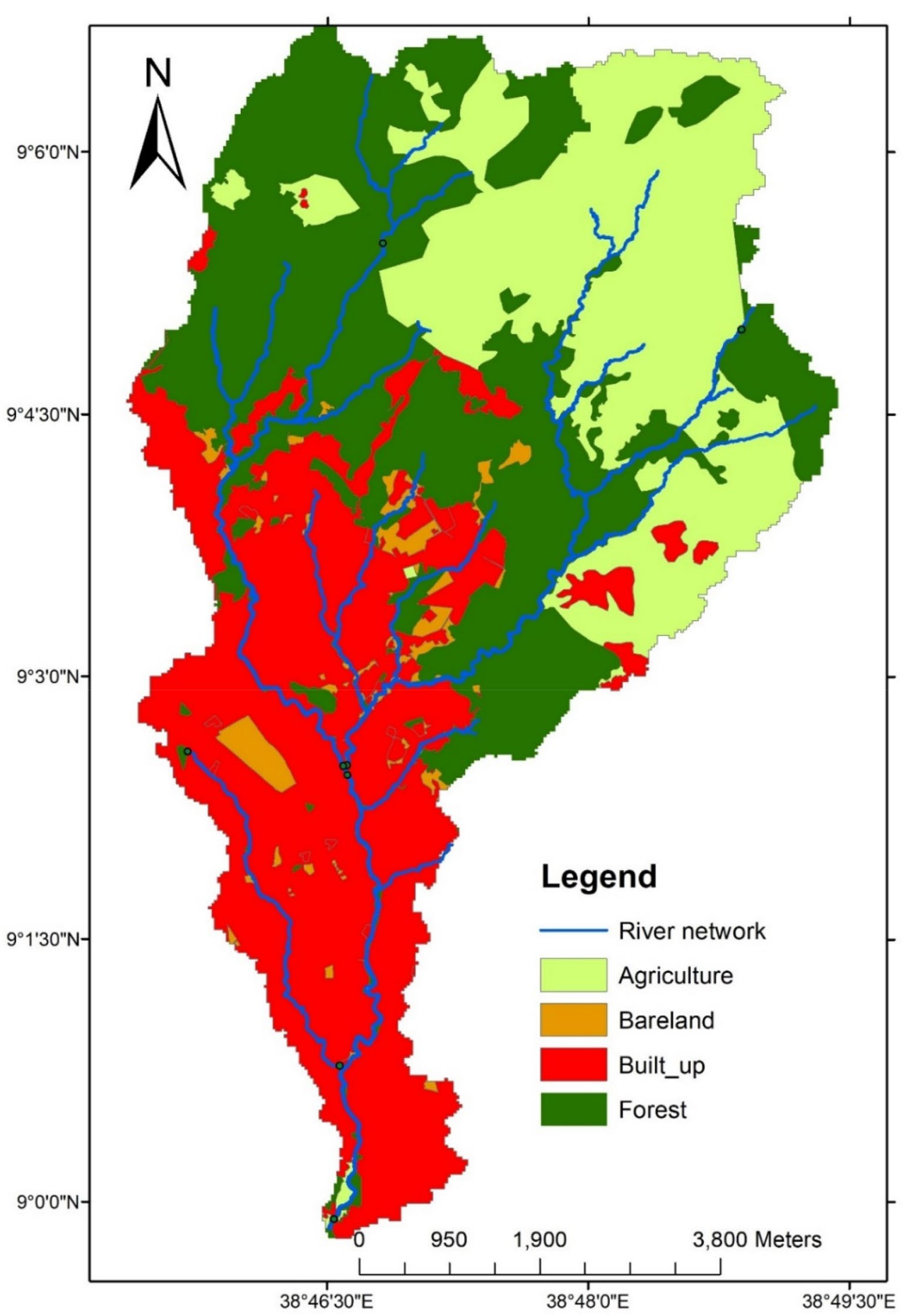

Fig. 4 Map of Land Use types of the catchments within the Kebena River Watershed

followed by forest dominated little-Kebena sub-watershed with a value of 5.92 and urban dominated Ginfle sub-watershed with a value of 6.64. Besides, in the dry season, the mean $\mathrm{pH}$ value of the river water at the source is 7.04 , whereas lower $\mathrm{pH}$ value was reported to be 7.65 in the urban dominated sub-watershed of Ginfile, 8.00, in forest dominated sub-watershed of Little-Kebena and 8.08 in the agriculture dominated subwatershed of Denkaka. 
Table 1 Land use types of the three sub-watersheds (Source: Digitized from aerial photograph of 2016)

\begin{tabular}{|c|c|c|c|c|c|c|c|c|c|c|}
\hline \multirow[t]{2}{*}{ Sub-Watersheds } & \multicolumn{2}{|c|}{ Built-up or settlement } & \multicolumn{2}{|c|}{ Cultivated land } & \multicolumn{2}{|c|}{ Forest land } & \multicolumn{2}{|l|}{ Bare land } & \multicolumn{2}{|l|}{ Total } \\
\hline & Area $(\mathrm{Ha})$ & $\%$ & Area $(\mathrm{Ha})$ & $\%$ & Area $(\mathrm{Ha})$ & $\%$ & Area $(\mathrm{Ha})$ & $\%$ & Area $(\mathrm{Ha})$ & $\%$ \\
\hline Denkaka (ADSW) & 474.40 & 19.17 & 1110.90 & 44.90 & 844.80 & 34.14 & 44.10 & 1.78 & 2474.20 & 100 \\
\hline Little-Kebena (FDSW) & 356.80 & 21.50 & 282.10 & 17.00 & 1010.10 & 60.87 & 10.40 & 0.63 & 1659.40 & 100 \\
\hline Ginfle (UDSW) & 350 & 90.44 & 29 & 7.49 & 6 & 1.55 & 2 & 0.52 & 387 & 100 \\
\hline Lower part of Kebena & 524.97 & 72.21 & 7.84 & 1.07 & 192.87 & 26.53 & 1.31 & 0.18 & 727 & 100 \\
\hline Total area of Kebena & 1706.17 & 32.51 & 1429.84 & 27.25 & 2053.77 & 39.14 & 57.81 & 1.10 & 5247.6 & 100 \\
\hline
\end{tabular}

Table 2 Mean values of seasonal water quality indicators in the Kebena watershed

\begin{tabular}{|c|c|c|c|c|}
\hline \multirow[t]{2}{*}{ Variable } & \multicolumn{2}{|l|}{ Season } & \multirow[t]{2}{*}{$\mathrm{t}$-Value } & \multirow[t]{2}{*}{$P$-Value } \\
\hline & Wet & Dry & & \\
\hline $\mathrm{PH}$ & 6.23 & 7.87 & -14.609 & $0.000^{* *}$ \\
\hline Total Dissolved Solid (TDS) mg/l & 255.00 & 900.00 & -35.514 & $0.000^{* *}$ \\
\hline Total Suspended Solid (TSS) mg/l & 101.38 & 156.00 & -2.242 & $0.030^{*}$ \\
\hline Electrical Conductivity (EC) $\mu \mathrm{s} / \mathrm{cm}$ & 444.50 & 1801.19 & -35.362 & $0.000^{* *}$ \\
\hline Ammonia, mg/l & 6.63 & 84.29 & -12.218 & $0.000^{* *}$ \\
\hline Total Nitrogen (TN), mg/l & 6.30 & 75.86 & -10.758 & $0.000^{* *}$ \\
\hline Total Phosphorus (TP), mg/l & .55 & 8.24 & -6.987 & $0.000^{* *}$ \\
\hline Chloride, mg/l & 51.92 & 87.71 & -10.443 & $0.000^{* *}$ \\
\hline $\begin{array}{l}\text { Chemical Oxygen Demand, } \\
\text { (COD), mg/l }\end{array}$ & 63.00 & 99.73 & -3.354 & $0.001^{* *}$ \\
\hline $\begin{array}{l}\text { Biological Oxygen Demand, } \\
\text { (BOD), mg/l }\end{array}$ & 25.28 & 64.63 & -3.356 & $0.002^{* *}$ \\
\hline
\end{tabular}

Analysis of the results showed that EC and TDS values in the three catchments and Kebena watershed are higher with no significant variations during the dry season, and the ANOVA result also revealed the same $(\mathrm{F}=0.079$ and 0.486 for EC and TDS, respectively, $P>0.05$ ).

However, the TSS value displays substantial variability with $\mathrm{F}=25,56$ and $\mathrm{P}<0.01$ during the dry seasons. On the other hand, during the wet seasons, the findings of ANOVA showed that the mean values of both EC, TDS and TSS display major differences across the three catchments and Kebena with $\mathrm{F}=122,51,35,87$ and 22,77 respectively, at $\mathrm{P}<0.01$ ) (Table 3 ).

The results, therefore, indicated that at the source of the Little-Kebena catchment, the value of COD accounts for 14 and $12 \mathrm{mg} / \mathrm{l}$ while the mean value of BOD is registered to be 2.4 and $10.8 \mathrm{mg} / \mathrm{l}$ during the wet and dry seasons, respectively.

The value of COD increase to 39 and $46 \mathrm{mg} / \mathrm{l}$, during the wet and dry seasons, respectively, at the lower end of the catchment. Similarly, the value of COD at the lower part of Denkaka catchment increases in both the rainy $(55 \mathrm{mg} / \mathrm{l})$ and dry seasons $(34 \mathrm{mg} / \mathrm{l})$. Moreover, at the Ginfle catchment, the value of COD is registered to be $114.00 \mathrm{mg} / \mathrm{l}$ during the rainy and $157.00 \mathrm{mg} / \mathrm{l}$ during the dry seasons. The BOD value also increases for the two catchments during the dry season which are $40.2 \mathrm{mg} / \mathrm{l}$

Table 3 Mean values of water quality indicators in the sub-watersheds in different seasons

\begin{tabular}{|c|c|c|c|c|c|c|c|c|c|c|c|c|}
\hline \multirow[t]{2}{*}{ Variable } & \multicolumn{2}{|c|}{$\begin{array}{l}\text { Forest } \\
\text { dominated } \\
\text { (Little- } \\
\text { Kebena) }\end{array}$} & \multicolumn{2}{|c|}{$\begin{array}{l}\text { Agriculture } \\
\text { dominated } \\
\text { (Denkaka) }\end{array}$} & \multicolumn{2}{|c|}{$\begin{array}{l}\text { Urban } \\
\text { dominated } \\
\text { (Ginfle) }\end{array}$} & \multicolumn{2}{|c|}{$\begin{array}{l}\text { Entire Kebena } \\
\text { watershed }\end{array}$} & \multirow[t]{2}{*}{ F Value (Dry) } & \multirow[t]{2}{*}{ Sig. (Dry) } & \multirow[t]{2}{*}{ F Value (Wet) } & \multirow[t]{2}{*}{ Sig. (Wet) } \\
\hline & dry & wet & dry & wet & dry & wet & dry & wet & & & & \\
\hline $\mathrm{PH}$ & 8 & 5.92 & 8.08 & 5.64 & 7.65 & 6.64 & 7.77 & 6.71 & 6.98 & $0.001^{* *}$ & 12.48 & $0.000^{* *}$ \\
\hline TDS mg/l & 885 & 170 & 917 & 279 & 921 & 362 & 877.00 & 209.00 & .83 & .486 & 35.87 & $0.000^{* *}$ \\
\hline TSS mg/l & 56 & 150 & 36 & 81 & 339 & 72.5 & 193.00 & 102.00 & 25.56 & $0.000^{* *}$ & 22.77 & $0.000^{* *}$ \\
\hline $\mathrm{EC}$ & 1766 & 339 & 1831.6 & 235.2 & 1853 & 784.7 & 1754.15 & 419.10 & 2.46 & .079 & 122.51 & $0.000^{* *}$ \\
\hline Ammonia, mg/l & 49.5 & 2.51 & 65 & 0.75 & 138.1 & 18.25 & 84.55 & 5.00 & 32.94 & $0.000^{* *}$ & 648.15 & $0.000^{* *}$ \\
\hline $\mathrm{T}-\mathrm{N}, \mathrm{mg} / \mathrm{l}$ & 42.45 & 4.1 & 54 & 3 & 129 & 10 & 78.00 & 8.10 & 25.77 & $0.000^{* *}$ & 47.05 & $0.000^{* *}$ \\
\hline $\mathrm{T}-\mathrm{P}, \mathrm{mg} / \mathrm{l}$ & 4.3 & 0.12 & 4.4 & 0.37 & 16.09 & 1.55 & 8.16 & 0.15 & 11.58 & $0.000^{* *}$ & 46.65 & $0.000^{* *}$ \\
\hline Chloride, mg/l & 94.22 & 44.25 & 102.83 & 36.61 & 79.2 & 78.8 & 74.59 & 48.00 & 35.66 & $0.000^{* *}$ & 110.34 & $0.000^{* *}$ \\
\hline COD, mg/l & 46 & 39 & 34 & 55 & 157 & 114 & 161.90 & 44.00 & 353.01 & $0.000^{* *}$ & 165.74 & $0.000^{* *}$ \\
\hline BOD, mg/l & 40.2 & 10.2 & 23 & 11.9 & 12.1 & 63 & 183.20 & 16.00 & 754.83 & $0.000^{* *}$ & 287.12 & $0.000^{* *}$ \\
\hline
\end{tabular}

** and * Significant at $1 \%$ and $5 \%$ significance level respectively 
for Little-Kebena and $23 \mathrm{mg} / \mathrm{l}$ for Denkaka catchments. However, the lowest value is registered for Ginfle catchment, which is $12.1 \mathrm{mg} / \mathrm{l}$.

The ANOVA result also shows the significant variation between the three catchments, Kebena watershed and COD results during both the wet and dry seasons with $\mathrm{F}=165.74$ and 287.12 , respectively at $P<0.01$ ). Furthermore, the ANOVA result revealed significant differences between the three catchments, Kebena watershed for BOD values during the wet and dry seasons with $\mathrm{F}=287.12$, and 754.83 , respectively at $P<0.001$.

During the wet and dry seasons, the mean value of Ammonia at the source of Little-Kebena catchment was found to be 1.25 and $0.001 \mathrm{mg} / \mathrm{l}$, respectively. The result also revealed that Genfle showed high amount of Ammonia during both the wet and dry seasons with $18.25 \mathrm{mg} / \mathrm{l}$ and $138 \mathrm{mg} / \mathrm{l}$, respectively. Similarly, the ANOVA result confirms a significant disparity between the three catchments, Kebena watershed and Ammonia results during both the wet $(\mathrm{F}=648.15, P<0.01)$ and dry $(\mathrm{F}=32.94$, $P<0.001)$ seasons.

According to the results, the mean values of Total Phosphorous (TP) at the source of Little-Kebena are found to be 0.5 and $8.6 \mathrm{mg} / \mathrm{l}$ during the wet and dry seasons, respectively. While the results of Total Nitrogen (TN) are registered to be 14 and $9 \mathrm{mg} / \mathrm{l}$ during the wet and dry seasons, respectively. The amount of TP increases towards the lower part of Little-Kebena and Ginfle catchment while decreasing in Dekaka catchment. With regards to TN the value was found to be lower during the rainy season in all the three sub-watersheds with a mean value of $4.1,3$, and $10 \mathrm{mg} / \mathrm{l}$ in Little-Kebena, Denkaka and Ginfle sub-watersheds, respectively. During the dry season, these values increased intensely in all three catchments and Kebena watershed whereby the highest mean value was recorded at Ginfle catchment with a value of $129 \mathrm{mg} / \mathrm{l}$.

The ANOVA result also shows a significant relationship between the three catchments, Kebena watershed and TP results during wet seasons with $(\mathrm{F}=46.65, P<0.001)$, and TP at Ginfle catchment was found to be very high with $1.55 \mathrm{mg} / \mathrm{l}$. During the dry season The ANOVA result also confirmed a significant variation with $(\mathrm{F}=11.58$, $P<0.001$ ), where a high value was recorded from Ginfle catchment with $16.09 \mathrm{mg} / \mathrm{l}$. Furthermore, the ANOVA results confirmed the significant relationships between the three catchments, Kebena watershed on the TN concentration during wet seasons $(\mathrm{F}=47.05, P<0.001)$, and dry seasons $(\mathrm{F}=25.77, P<0.001)$.

The result of the Chloride analysis at the source of Little Kebena was found to be 22.2 and 10.4 during the wet and dry seasons, respectively. The high level of Chloride $(102.8 \mathrm{mg} / \mathrm{l})$ during the dry season is registered in the Denkaka catchment while the lowest value was recorded to be $79.2 \mathrm{mg} / \mathrm{l}$ at Ginfle catchment. During the rainy season, a high amount of Chloride, i.e., $78.8 \mathrm{mg} / \mathrm{l}$ was recorded in Gifle catchment while the lowest was found to be $36.61 \mathrm{mg} / \mathrm{l}$ at Denkaka watershed. The ANOVA results also revealed the significant differences between the three catchments, Kebena watershed and Chloride at $(\mathrm{F}=110.34$ and $P<0.001)$ during the wet and at $\mathrm{F}=35.66$ and $P<0.001$ ) during the dry seasons.

\section{Watershed land use and water quality indicators}

Compared to water quality indicators at the source of the forest dominated catchment, the Urban dominated (Ginfle) and the forest dominated (Little-Kebena) sub-watersheds appeared to have the greatest effect on water quality during both the wet and dry seasons than the agriculture dominated (Denkaka) sub-watershed (Table 4). During the wet season, the Ginfle sub-watershed showed a strong positive relationship with all the water quality indicators except $\mathrm{pH}$. Whereas, forest dominated sub-watershed showed a positive relationship with all the water quality indicators except $\mathrm{pH}, \mathrm{TN}$, and TP. In contrast, TN showed a negative relationship with all the watersheds at $P<0.01$ level, with $\mathrm{R}^{2}$ value of 0.86 . Whereas TP showed a strong negative relationship with all the sub-watersheds except Ginfle with $\mathrm{R}^{2}$ of 0.76 , and $\mathrm{pH}$ showed a strong negative relationship with Little-Kebena and Denkaka sub-watersheds at $P<0.1$ level. The urban dominated sub-watershed appeared to have the greatest effect on water quality (Table 4). The TDS, TSS, EC, Ammonia, TN, TP, Chloride and COD showed strong positive relationship at $P<0.01$. The $\mathrm{pH}$ showed a positive relationship at $P<0.05$, while BOD showed no relationship.

During the dry season, the forest dominated subwatershed showed higher value of water quality indicators in which the $\mathrm{pH}$, TDS, EC, Ammonia, T-N, Chloride, COD, and BOD were strongly and positively related (Table 4). The agriculture dominated sub-watershed, though revealing lower water quality indicators during the dry season, still exhibits a strong positive relationship with $\mathrm{pH}, \mathrm{TDS}, \mathrm{EC}$, Ammonia, TN, Chloride, COD, and BOD at $P<0.01$ level.

In general, the Kebena water quality result at the end of the watershed when compared with the source revealed more serious effect during both the wet and dry seasons since all the water quality indicators showed strong positive relationship except BOD and $\mathrm{pH}$. The latter two parameters were found to be negatively related with the watershed's land use. 
Table 4 Results of multiple regression analysis on the effect of land use, within the three sub watersheds and Kebena watershed, on water quality over two seasons (+ represents positive while-represents a negative relationship)

\begin{tabular}{|c|c|c|c|c|c|}
\hline Wet & $\begin{array}{l}\text { FDSW } \\
\text { (Little- } \\
\text { Kebena) }\end{array}$ & $\begin{array}{l}\text { ADSW } \\
\text { (Denkaka) }\end{array}$ & $\begin{array}{l}\text { (UDSW) } \\
\text { Ginfle }\end{array}$ & Kebena & $R^{2}$ \\
\hline $\mathrm{PH}$ & $-0.81^{* *}$ & $-1.09^{* *}$ & -0.10 & -0.02 & 0.54 \\
\hline TDS & $135.37^{* *}$ & $244.37^{* *}$ & $327.37^{* *}$ & $174.37^{* *}$ & 0.89 \\
\hline TSS & $109.3^{* *}$ & $40.3^{* *}$ & $31.8^{* *}$ & $61.3^{* *}$ & 0.77 \\
\hline EC & $270.73^{* *}$ & $166.93^{* *}$ & $716.43^{* *}$ & $350.83^{* *}$ & 0.94 \\
\hline Ammonia & $1.26^{* *}$ & -0.50 & $17.0^{* *}$ & $3.75^{* *}$ & 0.98 \\
\hline $\mathrm{TN}$ & $-10.3^{* *}$ & $-11.4^{* *}$ & $-4.4^{* *}$ & $-6.3^{* *}$ & 0.86 \\
\hline TP & $-0.43^{* *}$ & -0.18 & $1.0^{* *}$ & $-0.40^{* *}$ & 0.76 \\
\hline Chloride & $21.83^{* *}$ & $14.19^{* *}$ & $56.38^{* *}$ & $25.58^{* *}$ & 0.91 \\
\hline COD & $24.9^{* *}$ & $40.9^{* *}$ & $99.9^{* *}$ & $29.9^{* *}$ & 0.95 \\
\hline $\mathrm{BOD}$ & $7.65^{* *}$ & $9.35^{* *}$ & $60.45^{* *}$ & $13.4^{* *}$ & 0.97 \\
\hline \multicolumn{6}{|l|}{ Dry } \\
\hline $\mathrm{PH}$ & $0.59^{* *}$ & $0.67^{* *}$ & $0.23^{*}$ & $0.36^{* *}$ & 0.57 \\
\hline TDS & $754.24^{* *}$ & $786.24^{* *}$ & $790.24^{* *}$ & $746.24^{* *}$ & 0.95 \\
\hline TSS & -26.85 & -46.85 & $256.15^{* *}$ & $110.15^{* *}$ & 0.68 \\
\hline $\mathrm{EC}$ & $1494.84^{* *}$ & $1560.44^{* *}$ & $1581.84^{* *}$ & $1482.99^{* *}$ & 0.98 \\
\hline Ammonia & $38.95^{* *}$ & $54.45^{* *}$ & $127.55^{* *}$ & $74.0^{* *}$ & 0.84 \\
\hline $\mathrm{TN}$ & $33.15^{* *}$ & $44.7^{* *}$ & $119.7^{* *}$ & $68.7^{* *}$ & 0.79 \\
\hline TP & -4.64 & -4.54 & $7.16^{* *}$ & -0.78 & 0.42 \\
\hline Chloride & $83.18^{* *}$ & $91.79^{* *}$ & $68.16^{* *}$ & $63.55^{* *}$ & 0.97 \\
\hline COD & $33.5^{* *}$ & $21.5^{* *}$ & $144.5^{* *}$ & $149.4^{* *}$ & 0.98 \\
\hline BOD & $29.28^{* *}$ & $12.08^{* *}$ & 1.18 & $172.28^{* *}$ & 0.99 \\
\hline
\end{tabular}

The reference water quality indicator is Forest source point $*$ and $*$ are significant at $1 \%$ and $5 \%$ levels, respectively

\section{Discussion}

Seasonal variations of water pollution in the Kebena River The water quality in the Kebena River was found to be deteriorated during the wet and dry seasons due to pollutants originating from various sources in the watershed. The results in this study are in agreement with earlier studies in the watershed (AACPPO 2017; Worku and Giweta 2018). The clear deterioration in the dry season water quality suggests that the pollution sources are mainly from point sources located at different parts of the river course (Worku and Giweta 2018). This is possibly true because in most of the places along the river course, liquid wastes from nearby residential settlements and other land uses are directly connected to the river through open ditches and road side drainage lines, aggravating the impact during the dry season as there is no rain to dilute the river water.

During the wet season, the mean value of $\mathrm{pH}$ (6.23) of Kebena river was below the range of the permissible limits, which is $6.5-8.5 / 9$, (WHO 1993) showing mainly of acidic character assumed to be resulting from the heavy rain during the wet season. This limits the potential of the river water to deliver various ecosystem services during the rainy seasons. However, during the dry season, the average $\mathrm{pH}$ value of the river water is 7.87 which makes it suitable to provide various ecosystem services (WHO 1993).

The fact that mean values of TSS, EC, Ammonia, TP, and $\mathrm{TN}$ are significantly higher during both the wet and dry seasons, compared to surface water quality standards is assumed to be associated with high amount of direct sewage discharges (Gibb 2000). Nitrogen and phosphorus concentrations are often high in areas with high anthropogenic inputs, (Carpenter et al. 1998). Furthermore, the value of EC is highly affected by temperature, which validates the higher value of EC in Kebena river during the dry season (Moore et al. 2008). Large nutrient loads of nitrogen (TN) and phosphorus (TP) can have somewhat specific routes, partially due to land use, building drainage and impermeable paved surfaces, and leaf litter dropping from cultivated trees (Teurlincx et al. 2019). The potential sources of phosphorus specially during the dry seasons in urban catchments might be related to wastewater disposals, and in-stream bathing and laundry activities (Dumago et al. 2018; Pieterse et al. 2003; Paul and Meyer 2001).

On the contrary, Chloride and COD showed significantly lower values in the wet season compared to surface water quality standards, which might be related to the diluting effect of the rain water during this season which affects the concentration of salts and other minerals (Giglioli and King 1966).

\section{Relation between watershed land use and water quality}

The study also compared water quality indicators from source of the forest-dominated catchment of the Little Kebena River with samples collected from the lower point of Little-Kebena watershed itself, the urban-dominated Ginfle catchment, and the agricultural-dominated Denkaka catchment in order to identify the catchment with a higher effect on the water quality of the river. Accordingly, the result revealed a positive relationship between the urban dominated catchment land use and various water quality indicators such as, Total Nitrogen, Total Phosphorous, Chloride, COD and BOD, which were observed during both the dry and wet seasons. The high amount of TP observed in Little-Kebena and Ginfle catchments during the wet seasons, could be due to the existence of large impervious surfaces coverage within the catchments. Therefore, the water quality of Ginfle river revealed high water pollution during both the wet and dry seasons, which is highly supported by many studies that concluded water quality of rivers found 
in highly urbanized watersheds are positively related to various water quality parameters (Brabec 2009; Sliva and Williams 2001). According to earlier studies, high runoff in urban watersheds is directly related to high watershed imperviousness. Giri and Qiu (2016), Schueler (1994) and Klien (1979) conversed that the degradation of the river water quality is extreme to the point where it is almost unavoidable at $30 \%$ of the imperviousness of watersheds.

Contrary to most researches such as Ding et al. (2015), Sliva and Williams (2001) the forest dominated subwatershed with $60.87 \%$ of forest cover shows a positive relationship with a number of water quality indicators such as Chloride, COD and BOD, and TSS during the wet season while pH, TDS, EC, Ammonia, TN, Chloride, $\mathrm{COD}$ and $\mathrm{BOD}$ are positively related during the dry season. This positive relationship of the river water with the above mentioned indicators could be attributed to the discharge of liquid waste from closely developed settlements in the middle and lower catchments of Little Kebena River, as discussed by (Brabec 2009); whereby the location of development within a given watershed plays an important role in water quality variability in addition to the percentage of watershed imperviousness. The structural plan also confirmed that some parts of the upper watersheds are occupied by informal settlements and industries (AACPPO 2017). Land degradation is also another major challenge aggravating soil erosion, specially within the Eucalyptus plantation (AACPPO 2017) which explains the large amount of TSS and TDS in Kebena River water.

The agriculture dominated sub-watershed with 19.17\% and forest dominated sub-watershed with $(21.50 \%)$ of their land being built-up, lie within the imperviousness cover ratio of $12-30 \%$ where the impact of the watershed is considered as minimal. Thus, controlling further impervious surface increment of the watersheds, while delineating proper river buffer zones, guiding upcoming developments, and implementing proper water pollution instruments is significantly crucial for the improvement of Kebena river water quality. Planning documents along with Building Permit Directives can be used as tools to guide and monitor development and imperviousness ratio of institutions and individual compounds.

\section{Planning Implication to water pollution mitigation in the urban settings}

The City Structural Plan confirmed that high pollution of river waters emanates from domestic and industrial wastewater discharges as well as storm runoff, thus, suggested various ways to prevent pollution of rives (AACPPO 2017). In line with this, the structure plan outlined that one of the effective ways to lower point source pollution influx to Kebena river catchments is by introducing new and upgrading of existing Waste Water Treatment Plants (WWTPs) (Paul and Meyer 2001; Björklund 2015). Furthermore, the structure plan delineated river buffer zone around the rivers of Addis Ababa with the width of 10-30 m to be covered with indigenous trees and shrubs, as riparian zones play a critical role in affecting stream health (Gregory et al. 1991). The structure plan also forwarded a way of considering the slope of riversides and various ways of developing these sloped riversides as green buffer zone (AACPPO 2017).

However, the suggested river water pollution prevention methods lack a watershed level perspective that will contribute to the fragmented and site-specific river management gaps of the study area. More importantly, the proposed environmental solutions of the Structural Plan are not synergized with the current and proposed land use, road networks and other planning features. This highly demeans the contribution to the planning decisions to prevent the river water pollution which is one of the main challenges of the city. Watershed planning, therefore, becomes as one of the vital tools to addresses water quality problems in a holistic manner by fully assessing the potential contributing causes and sources of pollution, then prioritizing restoration and protection strategies to address these problems (Ding et al. 2015; Arnold and Gibbons 1996).

In the case of the Kebena river watershed, different watershed level planning approaches are required for the three sub-catchments so as to address the varying issues. For instance, in Ginfle catchment where $90 \%$ of the watershed is built up, there is significant need for a comprehensive watershed planning that emphasizes on preventing further river degradation while focusing on site level design that reduces runoff and imperviousness, (Arnold and Gibbons 1996). Designing riversides in a manner that removes and cleanses much of the stormwater pollution that comes from the city before it joins the river is vital (Prominski et al. 2017). Furthermore, planning solutions should emphasize on emission reduction and enhancement of ecosystem conservation, as one of the Dublin Principles of 1992 (ICWE 1992) which concerns river basin management at the lowest appropriate level (Kemper et al. 2007). In line with this, it is necessary to remove polluting land uses, incorporate open ditches, small streams, and roads with environmentally suitable storm water management network, and establish adequate river buffer while reconnecting green patches within the catchment. Furthermore, it is crucial to incorporate water pollution mitigation schemes into urban planning decisions through provision of compact development approach, and brown field development approaches to reduce natural landscape composition fragmentation (Xu et al. 2019), and riparian buffers 
development to control further increment of impervious surfaces (Xu et al. 2019; Chouli et al. 2007; Mander et al 1997).

With regards to Little-Kebena catchment, where there is lower imperviousness ratio, river pollution mitigation measures should focus on preventive measures to retain the existing natural green spaces through open space planning, development and management schemes (Arnold, and Gibbons 1996). Moreover, location of development within the catchment plays a significant role in affecting water quality in an urbanized watershed whereby upland land use are critical in determining overall stream function, degradation, and rehabilitation potential (Booth and Jackson 1997; Barbec 2009). Thus, in this catchment, there is a possibility of extending the forest in the upper catchment to the lower catchment by limiting the various land uses that are polluting the river.

In Denkaka catchment, on the other hand, there is a crucial need for the provision of large river buffer zones to control runoff pollution coming mainly from crop fields, and settlements developed close to the river.

While developing watershed planning is crucial to preventing urban river pollution, its contribution will be limited if not adequately integrated with urban plans to facilitate its implementation and ensure its sustainability (Bernhardt and Palmer 2007). Therefore, the findings of this study suggest that land use planning need to be combined with scientific analysis of land uses and possible sources of pollutants in order to achieve effective restoration and maintenance of river water quality.

\section{Conclusions}

The study tried to explore how watershed land uses affected the water quality of the Kebena river at different locations and seasons. Furthermore, the linkages between the level of pollution and the dominant land use types was examined in the sub-catchments.

The findings revealed that Kebena river is a highly polluted river, which limits its potential to deliver various ecosystem services. Major pollutants originating from various point and non-point sources in the three sub-catchments are the main causes for the degradation of the river water quality. Water from the Ginfle sub-watershed, where $90 \%$ of the area is covered by built-up area, is most polluted in both the wet and dry seasons. The main cause could possibly be direct discharges of sewage loads from residential houses, light industries, schools, open defecations and unmanaged runoffs. Pollutant influx from Little-Kebena subwatershed with $60 \%$ forest land use contributes to the river pollution in the dry and wet seasons. This shows that not only the largely developed area in the watershed but also the location of it is the main factor for causing river water pollution. The findings in this study can be utilized in watershed-level planning and management interventions to improve water quality of the Kebena River.

The results in this study add new contextual knowledge on how watershed land use impacts river water quality in emerging urbanizing sub-Saharan cities of Africa with similar climatic situation and development trend. The similarity in development trends and socio-economic contexts could possibly make this study applicable to other large cities in Ethiopia. Furthermore, the findings can be extended to rivers in other developing cities that are challenged with rapid urbanization and poor planning trends. In addition, the findings can be considered as an addition to policymakers and implementation agencies in their decision-making process to integrate the crucial role of watershed planning into overall city planning activities in general, and surface water quality issues in particular.

Finally, future research should focus on developing tools, which help to transfer the main principles of watershed planning into practice. Furthermore, more researches can be conducted to identify and integrate the impact of landscape characters of sub watersheds such as slope, vegetation, and soil characters to river water quality. Such studies will significantly advance our understanding on the integration of watershed planning principles into current river restoration activities in the country in particular and more widely in similar urban settings elsewhere.

\section{Acknowledgements}

We would like to thank the water quality analysis experts at the lab for their helpful assistance, and all the people who were involved during water sample collection.

\section{Authors' contributions}

Mrs. Kalkidan (main author) and Professor Hailu first conceived of the presented idea. While I (Kalkidan) developed the theory, performed the computations and wrote the manuscript with support from Dr Mekuria who verified the analytical methods and proof read and edited the paper several times.

Availability of data and materials

All data and materials applied for the research are presented in the main paper.

Ethics approval and consent to participate

"Not applicable".

Consent for publication

"Not applicable".

Competing interests

"The authors declare that they have no competing interests".

Financial competing interests

"Not applicable". 


\section{Author details}

${ }^{1}$ Ethiopian Institute of Architecture, Building Construction and City Development, Addis Ababa University, P.O. Box 518, Addis Ababa, Ethiopia. ${ }^{2}$ Center for Environmental Science, Addis Ababa University, Addis Ababa, Ethiopia.

Received: 27 September 2020 Accepted: 4 December 2020

Published online: 12 January 2021

\section{References}

Addis Ababa City Planning Project Office (AACPPO) (2017) Addis Ababa City Structure Plan. Draft final summary report (2017-2027). AACPPO, Addis Ababa, Ethiopia. https://c40-productionimages.s3.amazonaws.com/other _uploads/images/2036_Addis_Ababa_Structural_Plan_2017_to_2027. original.pdf?1544193458.

Alemayehu T (2001) The impact of uncontrolled waste disposal on surface water quality in Addis Ababa Ethiopia SINET. Ethiopian J Sci 24(1):93-104

APHA (2005) Standard methods for the examination of water and waste water, 21 st edn. American Public Health Association, Washington, DC

Arnold C, Gibbons C (1996) Impervious surface coverage: the emergence of a key environmental indicator. J Am Plan Assoc 62(2):243-258

Arthington ÁH, Naiman RJ, Mcclain ME, Nilsson C (2010) Preserving the biodiversity and ecological services of rivers: new challenges and research opportunities. Freshw Biol 55(1):1-16

Baron JS, Poff NL, Angermeier PL, Dahm CN, Gleick PH, Hairston NG Jr, Jackson RB, Johnston CA, Richter BD, Steinman AD (2002) Meeting ecological and societal needs for freshwater. Ecol Appl 12(5):1247-1260

Beyene A, Addis T, Kifle D, Legesse W, Kloos H, Triest L (2009) Comparative study of diatoms and macroinvertebrates as indicators of severe water pollution: case study of the Kebena and Akaki rivers in Addis Ababa, Ethiopia. Ecol Ind 9:381-392. https://doi.org/10.1016/j.ecolind.2008.05.001

Björklund V (2015) Water quality in rivers affected by urbanization: a case study in Minas Gerais, Brazil. Student thesis series INES.

Booth DB, Jackson CR (1997) Urbanization of aquatic systems: degradation thresholds, stormwater detection, and the limits of mitigation 1. JAWRA J Am Water Res Assoc 33(5):1077-1090

Brabec E, Schulte S, Richards P (2002) Impervious surfaces and water quality: a review of current literature and its implications for watershed planning. J Plan Lit 16(4):499-514

Brabec EA (2009) Imperviousness and land-use policy: toward an effective approach to watershed planning. J Hydrol Engin 14(4):425-433

Bernhardt ES, Palmer MA (2007) Restoring streams in an urbanizing world. Freshw Biol 52(4):738-751

Browner CM (1996) Watershed approach framework. US Enviromental Protection Agency, Washington

Carpenter SR, Caraco NF, Correll DL, Howarth RW, Sharpley AN, Smith VH (1998) Nonpoint pollution of surface waters with phosphorusand nitrogen. Ecol Appl 8(3):559-568

Carter J (2007) Urban planning, water, and the water framework directive: insights from theory and practice. Geogr J 173(4):330-342

Cettner A, Ashley R, Viklander M, Nilsson K (2013) Stormwater management and urban planning: lessons from 40 years of innovation. J Environ Plan Manage 56(6):786-801

Chebet EB, Kibet JK, Mbui D (2020) The assessment of water quality in river Molo water basin Kenya. Appl Water Sci 10(4):1-10

Chouli E, Aftias, E, Deutsch JC (2007) Applying storm water management in Greek cities: learning from the European experience. Desalination 210(1-3):61-68

Doerfer JT, Urbonas BR (2004) Urban watershed master planning for stream protection in the denver metropolitan area. In: Protection and restoration of urban and rural streams, p 51-60

Ding J, Jiang Y, Fu L, Liu Q, Peng Q, Kang M (2015) Impacts of land use on surface water quality in a subtropical River Basin: A case study of the Dongjiang River Basin, Southeastern China. Water 7(8):4427-4445

Dumago SWL, Puno GR, Ingotan SS (2018) Water quality assessment in various land use and land cover of Muleta watershed Bukidnon, Philippines. J Biol Environ Sci 12(3):201-209

Findlay SJ, Taylor MP (2006) Why rehabilitate urban river systems? Area 38:312-325. https://doi.org/10.1111/j.1475-4762.2006.00696
Fitzpatrick ML, Long DT, Pijanowski BC (2007) Exploring the effects of urban and agricultural land use on surface water chemistry, across a regional watershed, using multivariate statistics. Appl Geochem 22(8):1825-1840

Gebre G, Van Rooijen DJ (2009) Urban water pollution and irrigated vegetable farming in Addis Ababa

Gibb SW (2000) Ammonia. In: Nollet LML (ed) Handbook of water analysis. Marcel Dekker Inc., NewYork USA

Giglioli MEC, King DF (1966) The mangrove swamps of Keneba, Lower Gambia river basin. III. Seasonal variations in the chloride and water content of swamp soils, with observations on the water levels and chloride concentration of free soil water under a barren mud flat during the dry season. J Appl Ecol 1-19

Giri S, Qiu Z (2016) Understanding the relationship of land uses and water quality in Twenty First Century: a review. J Environ Manag 173:41-48

Goonetilleke A, Thomas E, Ginn S, Gilbert D (2005) Understanding the role of land use in urban stormwater quality management. J Environ Manage 74(1):31-42

Goshu G (2007) The physio-chemical characteristics of a highland crater lake and two reservoirs in north-west Amhara Region (Ethiopia). Ethiopian J Sci Technol 5(1):17-41

Gregory SV, Swanson FJ, McKee WA, Cummins KW (1991) An ecosystem perspective of riparian zones. BioScience 41(8):540-551

Gyawali S, Techato K, Monprapussorn S, Yuangyai C (2013) Integrating land use and water quality for environmental based land use planning for U-tapao river basin, Thailand. Proc Soc Behav Sci 91:556-563

Hudak PF, Banks KE (2006) Compositions of first flush and composite storm water runoff in small urban and rural watersheds, north-central Texas. Urban Water J 3(1):43-49

ICWE (1992) The dublin statement and report of the conference. In: International conference on water and the environment: development issues for the21st century, Dublin, 26-31 Jan 1992

Kemper KE, Blomquist W, Dinar A (2007) River basin management at the lowest appropriate level: when and why does it (not) work in practice? Integrated river basin management through decentralization. Springer, Berlin, Heidelberg, pp 3-15

Klein RD (1979) Urbanization and stream quality impairment 1. JAWRA J Am Water Res Assoc 15(4):948-963

Lee SW, Hwang SJ, Lee SB, Hwang HS, Sung HC (2009) Landscape ecological approach to the relationships of land use patterns in watersheds to water quality characteristics. Landsc Urban Plan 92(2):80-89

Leopold LB (1968) Hydrology for urban land planning: A guidebook on the hydrologic effects of urban land use, vol 554. US Department of the Interior, Geological Survey

Leta S, Mekonen A, Alemu E, Alemu T, Abate Z, Yilma E, Teshome G, Habtemariam H, Ragassa C, Sahle M, Soromessa T, Hussen A, Dessalign W, Birru D, Tsegaye D (2017) Pollution and sanitation study for addis ababa rivers and riversides development plan project, Center for Environmental Science. Addis Ababa University, Addis Ababa

Li S, Gu S, Liu W, Han H, Zhang Q (2008) Water quality in relation to land use and land cover in the upper Han River Basin. China Catena 75(2):216-222

Liang Z, Siegert M, Fang W, Sun Y, Jiang F, Lu H, Chen GH, Wang S (2018) Blackening and odorization of urban rivers: a bio-geochemical process. FEMS Microbiol Ecol 94(3):p.fix180

Lim HS, Lu XX (2016) Sustainable urban stormwater management in the tropics: an evaluation of Singapore's ABC Waters Program. J Hydrol 538:842-862

Mander Ü, Kuusemets V, Lõhmus K, Mauring T (1997) Efficiency and dimensioning of riparian buffer zones in agricultural catchments. Ecol Eng 8(4):299-324

Mazhindu E, Gumbo T, Gondo T (2012) Waste management threats to human health and urban aquatic habitats: a case study of Addis Ababa, Ethiopia. In: Rebellon LFM (ed) Waste management: an integrated vision. IntechOpen, p 21-54

Moore RD, Richards G, Story A (2008) Electrical conductivity as an indicator of water chemistry and hydrologic process. Streamline Watershed Manage Bull 11(2):25-29

Gober P, Larson KL, Quay R, Polsky C, Chang H, Shandas V (2013) Why land planners and water managers don't talk to one another and why they should! Soc Nat Res Int J 26(3):356-364. https://doi.org/10.1080/08941 920.2012 .713448 
Paul MJ, Meyer JL (2001) Streams in the urban landscape. Annu Rev Ecol Syst 32(1):333-365

Pieterse NM, Bleuten W, Jørgensen SE (2003) Contribution of point sources and diffuse sources to nitrogen and phosphorus loads in lowland river tributaries. J Hydrol 271(1-4):213-225

Prominski M, Stokman A, Stimberg D, Voermanek H, Zeller S, Bajc K (2017) River. Space. Design: Planning strategies, methods and projects for urban rivers. Birkhäuser

Schueler T (1994) The importance of imperviousness. Watershed protection techniques 1, vol. 3, p 100-101

Sliva L, Williams DD (2001) Buffer zone versus whole catchment approaches to studying land use impact on river water quality. Water Res 35(14):3462-3472

Spänhoff B, Dimmer R, Friese H, Harnapp S, Herbst F, Jenemann K, Mickel A, Rohde S, Schönherr M, Ziegler K, Kuhn K (2012) Ecological status of rivers and streams in Saxony (Germany) according to the water framework directive and prospects of improvement. Water 4(4):887-904

Teurlincx S, Kuiper JJ, Hoevenaar EC, Lurling M, Brederveld RJ, Veraart AJ, Janssen AB, Mooij WM, de Senerpont Domis LN (2019) Towards restoring urban waters: understanding the main pressures. Curr Opin Environ Sustain 36:49-58

US Environmental Protection Agency (1995) Watershed Protection: A Statewide Approach EPA 841-R-95-004 Office of Water (4503F). US Environmental Protection Agency, Nebraska, pp 16-24

Ward P, Pauw W, van Buuren M, Marfai M (2012) Governance of flood risk management in a time of climate change: the cases of Jakarta and Rotterdam. Environ Politics 22(3):518-536

White MD, Greer KA (2006) The effects of watershed urbanization on the stream hydrology and riparian vegetation of Los Penasquitos Creek, California. Landsc urban Plan 74(2):125-138
Weldegebriel Y, Chandravanshi BS, Wondimu T (2012) Concentration levels of metals in vegetables grown in soils irrigated with river water in Addis Ababa, Ethiopia. Ecotoxicol Environ Saf 77:57-63

Wilson C, Weng Q (2010) Assessing surface water quality and its relation with urban land cover changes in the Lake Calumet Area, Greater Chicago. Environ Manag 45(5):1096-1111

Worku Y, Giweta M (2018) Can We Imagine Pollution Free Rivers Around Addis Ababa city, Ethiopia? What were the wrong-doings? What action should be taken to correct them? J Pollut Eff Cont 6:228. https://doi. org/10.4172/2375-4397.1000228

World Health Organization (1993) Guidelines for drinking-water quality. World Health Organization

Xu G, Ren X, Yang Z, Long H, Xiao J (2019) Influence of landscape structures on water quality at multiple temporal and spatial scales: a case study of Wujiang River Watershed in Guizhou. Water 11(1):159

Yabe J, Ishizuka M, Umemura T (2010) Current levels of heavy metal pollution in Africa. J Vet Med Sci 72(10):1257-1263

Yohannes H, Elias E (2017) Contamination of rivers and water reservoirs in and around Addis Ababa City and actions to combat It. Environ Pollut Climate Change 01:1-12

\section{Publisher's Note}

Springer Nature remains neutral with regard to jurisdictional claims in published maps and institutional affiliations.

\section{Submit your manuscript to a SpringerOpen ${ }^{\odot}$ journal and benefit from:}

- Convenient online submission

- Rigorous peer review

- Open access: articles freely available online

- High visibility within the field

- Retaining the copyright to your article

Submit your next manuscript at $\boldsymbol{\nabla}$ springeropen.com 